\title{
UJI VIABILITAS BAKTERI ASAM LAKTAT DARI USUS YANG DIPREPARASI DALAM RANSUM UNGGAS
}

\author{
The Viability Test of Lactic Acid Bacteria from Intestine in Preparation on Poultry Ration \\ Rudy Sutrisna ${ }^{a}$, C. N. Ekowati ${ }^{b}$, Salman Farisi ${ }^{b}$, dan Hendra Verry Setyawan ${ }^{b}$

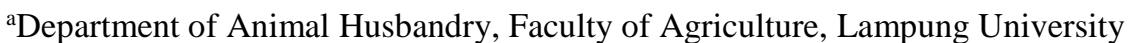 \\ Soemantri Brojonegoro No. 1, Gedong Meneng, Rajabasa, Bandar Lampung, Lampung Province \\ ${ }^{\mathrm{b}}$ Department of Animal Husbandry, State Polytechnic of Lampung \\ Soekarno Hatta No. 10, Bandar Lampung, Lampung Province \\ email: rudysutrisna65@yahoo.co.id
}

\begin{abstract}
The aim of this study is to know the viability of Lactic Acid Bacteria isolates on ration and combination of ration with molasses. This study used a mixture of lactic acid bacteria isolates from the duck intestine (B4, $B 7, B 8)$. The third bacterial isolates were inoculated on two different treatment media, on rantion media (R1), and combination of rantion + molasses $(R 2)$. The study was arranged by randomized block design (RAK) $6 \times 2$ factorial treatment pattern. Factor $A$ is the incubation time of 0 hours, 2 hours, 4 hours, 6 hours, 8 hours and 10 hours. Factor $B$ is two types of growing media of lactic acid bacteria, is ransum media, and combination of ransum + molasses. Each treatment was repeated 3 times. This research uses pour plate method with the calculation of the colony using colony counter. Data analyzed descriptively. The results showed that the addition of $1.6 \%$ molasses (R2) maintains the number of LAB population at 4th hour with the cell number 7,36 $x 10^{5} \mathrm{CFU} / \mathrm{g}$. While on the ration medium (R1) can maintain the amount of LAB at 6th hour with the cell number of 6,20 $\times 10^{5} \mathrm{CFU} / \mathrm{g}$. LAB population viability on feed medium with addition of molases $1.6 \%(R 2)$ has increased on storage time at 4th hour with cell number 7,36 x $10^{5} \mathrm{CFU} / \mathrm{g}$, while on feed medium (RI) decreased cell count $6,08 \times 10^{5} \mathrm{CFU} / \mathrm{g}$.
\end{abstract}

Keywords: Viability, Lactic Acid Bacteria, Ransum, Molase.

\section{PENDAHULUAN}

Bakteri asam laktat dapat bertahan hidup pada medium yang sesuai atau medium yang memiliki komposisi nutrisi yang dibutuhkan untuk pertumbuhannya. Menurut Pelczar dan Chan (2005) bakteri akan mampu mempertahankan diri dengan baik di dalam lingkungan selama kondisinya menguntungkan. Salah satu lingkungan yang berperan adalah media preparasi ransum.

Komposisi ransum menurut Saputro (2016) terdiri dari campuran bahan-bahan pakan yang meliputi dedak, tepung jagung, ampas tahu, tepung ikan, mineral, molases, minyak sawit, lisin, metionin lalu dibuat dalam bentuk pellet dan diberikan pada itik. Menurut Hidayat dan Suhartini (2006) molases dapat digunakan sebagai sumber karbon karena mengandung sukrosa 30-40 $\%$, glukosa 4-9 \%, dan fruktosa 5-12 \%. Hermawati (2013) menunjukkan bahwa molases $2 \%$ dan molases $1,5 \%$ merupakan konsentrasi paling optimal dalam meningkatkan daya simpan terhadap viabilitas bakteri asam laktat. Hasil penelitian Supriyanto et al., (2012), konsentrasi molases $2 \%$ adalah konsentrasi terbaik untuk pertumbuhan Lactobacillus plantarum.
Preparasi ransum dengan perbandingan 1 : 1 adalah perbandingan ransum dengan probiotik dengan kepadatan $10^{8} \mathrm{CFU} / \mathrm{ml}$ (Irianingrum, 2009), sehingga kandungan tepung ikan, molases dan bahan organik lain dapat mendukung viabilitas bakteri asam laktat dalam preparasi ransum itik.

Penelitian Irianingrum (2009) dalam pembuatan silase dedak padi menggunakan starter Bakteri Asam Laktat (BAL) dalam mempertahakan kualitas dan menurunkan kandungan asam fitat dari dedak padi yaitu $6,70 \%$ hingga mencapai $2,07 \%$ serta meningkatkan kecernaan bahan kering dan organic dalam keadaan anaerob selama 12 minggu.

\section{MATERI DAN METODE}

\section{Materi}

Alat yang digunakan dalam penelitian ini antara lain laminar air flow cabinet, tabung reaksi, autoclave, cawan petri, erlenmeyer, hot plate, micropippet dan pipet tip, kapas, kain kasa, colony counter, oven, pipet volumetri dan pump. Bahan yang digunakan dalam penelitian ini anatara lain meliputi isolat bakteri usus itik (B4, B7, dan B8) yang diperoleh dari koleksi (Sutrisna, 2013), 
media deMan Rogosa and Sharpe (MRS) Broth, media deMan Rogosa and Sharpe (MRS) Agar, $\mathrm{NaCl}$ steril, ransum dan ransum bermolases.

\section{Metode}

Penelitian disusun dengan percobaan Rancangan Acak Kelompok (RAK) pola perlakuan faktorial $6 \times 2$. Faktor $\mathrm{A}$ adalah lama waktu inkubasi 0 jam, 2 jam, 4 jam, 6 jam, 8 jam dan 10 jam. Faktor B adalah dua jenis media tumbuh BAL, yaitu media ransum, dan kombinasi media ransum + molases. Masing-masing perlakuan diulang sebanyak 3 kali.

Tahapan dalam penelitian ini yaitu

1. Peremajaan bakteri isolat B4, B7, dan B8 yang di campur menjadi satu dari usus itik diremajakan pada tabung reaksi yang berisi medium MRS Broth kemudian diinkubasi selama 48 jam di dalam inkubator pada suhu $37^{\circ} \mathrm{C}$.

2. Pembuatan inokulum isolat yang telah diinkubasi dari peremajaan diambil sebanyak 1 $\mathrm{ml}$ ke dalam $10 \mathrm{ml}$ MRS Broth steril kemudian diinkubasi selama 48 jam dalam incubator.

3. Pembuatan ransum dengan probiotik, suspensi bakteri uji diinokulasikan secara merata dengan perbandingan $50 \mathrm{ml}$ suspensi ( Standart Mac Farland $10^{8} \mathrm{CFU} / \mathrm{ml}$ ) untuk setiap 50 gram media pakan (Irianingrum, 2009) yaitu ransum (R1) dan kombinasi ransum + molases 1,6\% (R2). Campuran antara suspensi bakteri dengan media pakan dihomogenkan dan diinkubasi pada 0 jam, 2 jam, 4 jam, 6 jam, 8 jam dan 10 jam dalam cawan petri pada suhu ruang.

4. Perhitungan sel bakteri dilakukan secara tidak langsung dengan metode pour plate. Masingmasing sampel perlakuan diambil sebanyak 1 gram, lalu diencerkan dalam larutan garam fisiologis sebanyak $10 \mathrm{ml}$ sebagai pengenceran $10^{-1}$ dan seterusnya sampai pengenceran $10^{-9}$. Diambil sebanyak $1 \mathrm{ml}$ masing-masing dari 3 pengenceran tertinggi dituang kedalam cawan petri steril, kemudian ditambahkan medium MRS Agar sebanyak $15 \mathrm{ml}$. Cawan petri digoyangkan supaya suspensi dan media tercampur merata (Pour Plate Method). Setelah media memadat, diinkubasi dalam inkubator dengan suhu $37^{\circ} \mathrm{C}$ selama $48 \pm 2$ jam. Setelah diinkubasi dihitung jumlah koloni dengan menggunakan colony counter. Hasil pehitungan jumlah koloni kemudian dikonversikan ke dalam sel/ml.

Jumlah koloni BAL yang tumbuh kemudian dimasukkan kedalam rumus Angka Lempeng Total (ALT) sebagai berikut:

$$
\mathrm{N}=\frac{\Sigma \mathrm{C}}{(\mathrm{n} 1 \mathrm{x} 1)+(n 2 \times 0,1)} \times \mathrm{d}(\text { Kristiyanti, 2015). }
$$

$$
\begin{aligned}
& \text { Keterangan: } \\
& \begin{aligned}
\mathrm{N}= & \text { Jumlah koloni } / \text { gram } \\
\mathrm{\Sigma C} & =\text { Total koloni yang dapat dihitung } \\
\mathrm{n} 1= & \text { Jumlah cawan petri pada } \\
\mathrm{n} 2 & =\begin{array}{l}
\text { pengenceran pertama yang dihitung } \\
\text { pengenceran kedua yang dihitung }
\end{array} \\
\mathrm{d} & =\text { Pengenceran pertama yang dihitung }
\end{aligned}
\end{aligned}
$$

\section{HASIL DAN PEMBAHASAN}

\section{Pertumbuhan Isolat BAL pada Media Perlakuan}

Berdasarkan hasil perhitungan jumlah angka lempeng total menunjukkan bahwa penambahan molases pada media perlakuan memberikan pengaruh terhadap daya hidup BAL. Gambar 1 menunjukkan bahwa dengan penambahan molase $1,6 \%$ pada media ransum bermolases (R2) dapat bertahan sampai waktu penyimpanan 4 jam dengan jumlah populasi BAL tertinggi 7,36 x $10^{5} \mathrm{CFU} / \mathrm{g}$, kemudian menurun pada jam ke 6 menjadi $6,40 \times 10^{5}$ dan terus menurun pada pengamatan jam ke 8 . Gambar 2 menunjukkan daya tahan BAL pada media perlakuan ransum tanpa molase (R1) bertahan sampai waktu penyimpanan 6 jam yaitu sebesar $6,20 \times 10^{5} \mathrm{CFU} / \mathrm{g}$ dan terus menurun pada pengamatan jam ke 8 .

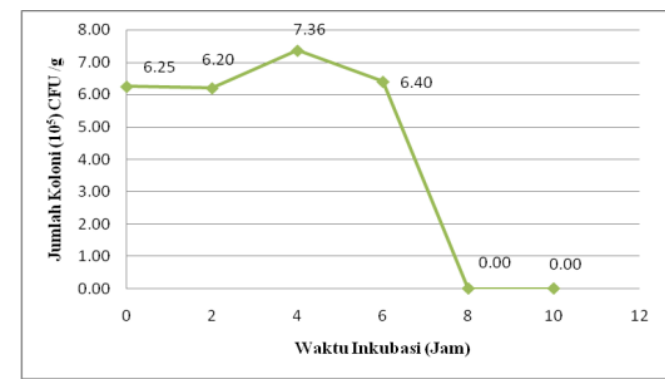

Gambar 1. Grafik pertumbuhan pada media ransum bermolases

Berdasarkan fase pertumbuhan BAL pada Gambar 1 yaitu fase lag terjadi pada jam ke-0 sampai dengan jam ke-2, sedangkan fase eksponen terjadi pada jam ke-2 sampai dengan jam ke-4, dan fase kematian terjadi pada jam ke-6 sampai dengan jam ke-10, sedangkan fase pertumbuhan BAL pada Gambar 2 yaitu fase eksponen terjadi pada jam ke-0, pada jam ke-2 sampai dengan jam ke-4 populasi bakteri mengalami fase penurunan, pada jam ke-6 mengalami peningkatan kembali, dan fase kematian terjadi pada jam ke-8 sampai jam ke-10.

Hasil penelitian, menunjukkan bahwa pada media perlakuan ransum dengan penambahan molase $1,6 \%$ (R2) meningkatkan secara signifikan 
terhadap pertumbuhan BAL dibandingkan dengan media ransum tanpa molase (R1). Berdasarkan hasil penelitian ini, maka daya tahan isolat BAL terhadap lama penyimpanan hanya sampai 4 jam pada (R2). Ditunjukkan pada Gambar 1 yaitu fase lag ditunjukkan pada jam ke-0 (awal inkubasi) campuran isolat BAL pada media ransum ber molase $1,6 \%$ (R2) jumlah selnya $6,25 \times 10^{5}$ CFU/g. Jumlah sel ini tetap bertahan (viable) hingga jam ke-2 yaitu 6,20 x $10^{5}$ CFU/g. Selanjutnya fase eksponen ditunjukkan pada jam ke-2 dengan jumlah sel 6,20 x $10^{5} \mathrm{CFU} / \mathrm{g}$. Jumlah sel ini tetap bertahan sampai dengan jam ke-4 yaitu $7,36 \times 10^{5} \mathrm{CFU} / \mathrm{g}$, dan mengalami penurunan yang ditunjukkan pada jam ke-4 dengan jumlah selnya $7,36 \times 10^{5} \mathrm{CFU} / \mathrm{g}$ sampai jam ke-6 yaitu dengan jumlah sel $6,40 \times 10^{5} \mathrm{CFU} / \mathrm{g}$. Pada jam ke8 dan ke-10 mengalami fase kematian ditandai dengan tidak adanya populasi bakteri yang tumbuh.

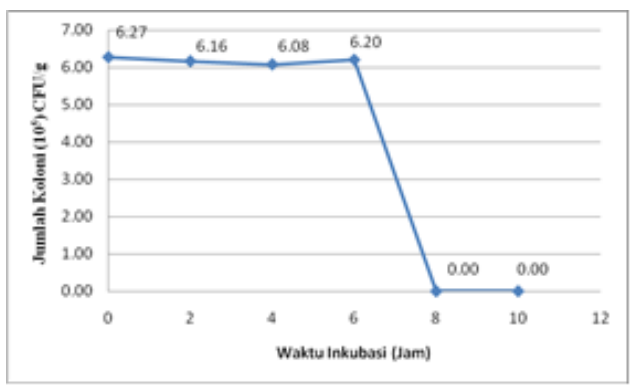

Gambar 2. Grafik pertumbuhan pada media

\section{Viabilitas Isolat BAL Dari Usus Itik Pada Media Perlakuan}

Berdasarkan hasil perhitungan jumlah koloni menggunakan rumus Kristiyanti, (2015) menunjukkan bahwa molase bakteri asam laktat menghasilkan viabilitas tertinggi yaitu pada media perlakuan ransum dengan penambahan molase $1,6 \%$ (R2) dibandingkan dengan media perlakuan ransum tanpa molase (R1). Perbedaan sigifikan ditunjukkan pada Gambar 3 yaitu terjadi peningkatan viabilitas populasi bakteri pada media ransum bermolases $1,6 \%$ (R2) yaitu pada jam ke-4 dengan jumlah 7,36 x $10^{5} \mathrm{CFU} / \mathrm{g}$, sedangkan pada media ransum tanpa molase (R1) viabilitas populasi bakteri sebesar $6,08 \times 10^{5} \mathrm{CFU} / \mathrm{g}$.

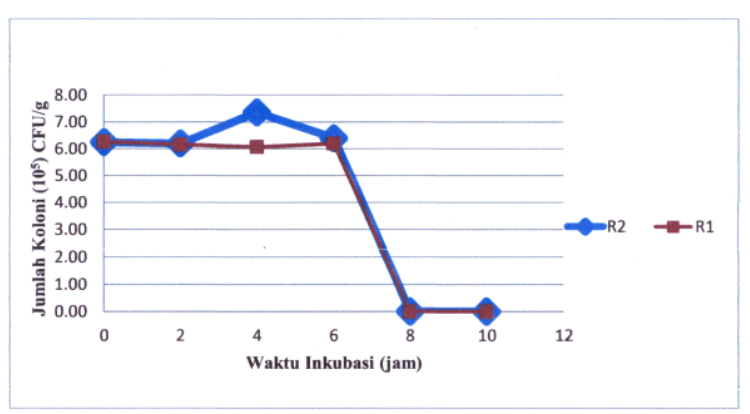

Gambar 3. Viabilitas isolat BAL sebagai kandidat probiotik dalam ransum
Berdasarkan persentase viabilitas pada media ransum dengan penambahan molase 1,6 $\%$ (R2) mengalami peningkatan viabilitas tertinggi yaitu terjadi pada jam ke-4 dengan jumlah sel 7,36 x $10^{5} \mathrm{CFU} / \mathrm{g}$. Pada waktu penyimpanan ke-0 jam sampai ke-2 jam persentase viabilitas BAL tidak menunjukkan perbedaan spesifik antara kedua media perlakuan karena BAL mengalami fase lag (fase penyesuaian diri). Pada fase lag campuran isolate $\mathrm{BAL}$ pada kedua media perlakuan mengalami adaptasi dengan perubahan lingkungan tempat hidupnya. Pada jam ke-2 dan jam ke-4 viabilitas BAL pada media ransum bermolases (R2) lebih tinggi karena molases mengandung gula dalam bentuk yang lebih sederhana dibandingkan dengan media ransum tanpa molasses (R1), sehingga mudah digunakan oleh bakteri untuk memacu proses pertumbuhan dan molasses. Pada jam ke-6 viabilitas BAL mengalami penurunan, karena pada waktu ini nutrisi yang telah didapatkan pada fase penyesuian diri telah habis. Pada jam ke-8 dan ke-10 viabilitas BAL mengalami fase kematian ditandai dengan tidak adanya populasi bakteri yang tumbuh.

Menurut Priyono (2009) molasses merupakan sumber molasse yang esensial dengan kandungan gula. Dengan demikian, molasses banyak dimanfaatkan sebagai bahan tambahan pakan ternak dengan kandungan nutrisi yang cukup baik. Molases memiliki kandungan protein kasar sebesar $3,1 \%$, serat kasar sebesar $0,6 \%$, senyawa molasse yang terdiri dari bahan ekstrak tanpa nitrogen sebesar $83,5 \%$, lemak kasar sebesar $0,9 \%$ dan abu sebesar $11,9 \%$.

Pada media ransum tanpa molasses (R1) populasi total bakteri cenderung stabil dengan waktu bertahan hidup cukup lama yaitu sampai jam ke-6, berbeda dengan media ransum dengan penambahan molasses $1,6 \%$ (R2) mengalami peningkatan yang signifikan dan bertahan hidup cukup singkat yaitu sampai jam ke-4. Pada jam ke-0 (awal inkubasi) pada media ransum jumlah sel $6,27 \times 10^{5} \mathrm{CFU} / \mathrm{g}$. Pada waktu ini populasi bakteri berada di fase eksponen, dimana fase ini mengalami peningkatan jumlah sel membelah dua kali lipat dengan kecepatan membelah yang sama. Pada jam ke-2 populasi bakteri mengalami penurunan yaitu dengan jumlah sel $6,16 \times 10^{5}$ CFU/g sampai pada jam ke-4 dengan jumlah sel $6,08 \times 10^{5} \mathrm{CFU} / \mathrm{g}$. Pada jam ke-6 populasi bakteri mengalami peningkatan kembali yaitu ditandai dengan adanya fase eksponen dimana fase ini mengalami peningkatan jumlah sel membelah dua kali lipat dengan kecepatan membelah yang sama yaitu dengan jumlah sel $6,20 \times 10^{5} \mathrm{CFU} / \mathrm{g}$, dan pada jam ke-6 pula populasi bakteri mengalami penurunan dengan jumlah sel 6,20 x $10^{5} \mathrm{CFU} / \mathrm{g}$. Pada jam ke-8 dan ke-10 populasi bakteri mengalami penurunan sekaligus mengalami fase 
kematian ditandai dengan tidak adanya populasi bakteri yang tumbuh.

Komposisi ransum menurut Saputro (2016) terdiri dari campuran bahan-bahan pakan yang meliputi dedak, tepung jagung, ampas tahu, tepung ikan, mineral, molase, minyak sawit, lisin, metionin lalu dibuat dalam bentuk pellet dan diberikan pada itik. Amrullah (2003) menambahkan bahwa penyusunan ransum itik petelur maupun pedaging memerlukan informasi mengenai kandungan nutrisi dari bahan-bahan penyusunnya, sehingga dapat mencukupi kebutuhan nutrisi molasses dalam jumlah dan persentase yang diinginkan. Nutrien dalam molase meliputi protein, serat kasar, kalsium (Ca) dan fosfor $(\mathrm{P})$. Sumber nutrien utama dalam molase yang terdapat dalam ransum adalah karbohidrat dan lemak sebagai sumber energi. Energi yang diperlukan itik berbeda, sesuai tingkat umurnya, jenis kelamin dan cuaca. Selain molase, nutrien yang terkandung dalam ransum perlakuan menjadi penentu lingkungan untuk bertahan hidupnya isolat BAL.

Pertumbuhan BAL meliputi proses yang kompleks, diawali dengan masuknya nutrisi ke dalam sel, kemudian nutrisi diubah menjadi organel sel. Selanjutnya digunakan untuk replikasi kromosom, setelah itu terjadi pembelahan sel menjadi dua sel anakan, kemudian terjadi peningkatan jumlah dan ukuran sel (Moat et al., 2002). Pelczar et al.,(1993) menyatakan gula merupakan nutrient utama sel yang digunakan untuk respirasi sel atau sumber energi utama. Metabolisme dapat menghasilkan glukosa yang diperlukan untuk kerja sel, sintesis organel sel dan untuk membentuk generasi baru.

Ransum sebagai media pertumbuhan BAL memiliki kandungan nutrien berupa protein, lemak, karbohidrat, bahan kering, serat kasar yang mungkin menyumbangkan nutrien bagi pertumbuhan BAL. Nutrien protein pada media ransum dalam bentuk lisin dan metionin, kedua asam amino tersebut merupakan monomer dari protein (Tarigan, 2010). Asam amino yang dihasikan dari perombakan protein digunakan sebagai sumber nitrogen untuk meningkatkan viabilitas BAL tersebut (Mardiani et al., 2013). Nutrien dalam jagung, mengandung lemak, dan dapat dipecah menjadi asam lemak, dan asam lemak akan digunakan oleh BAL untuk mempertahankan daya hidupnya. Nutrien karbohidrat pada ransum dalam bentuk dedak padi, Selain itu kandungan karbohidrat dedak padi juga cukup tinggi sekitar 40-49\% sehingga dapat digunakan sebagai sumber karbon untuk pertumbuhan BAL. Karbohidrat yang tersedia dedak padi merupakan sumber karbon untuk menghasilkan ATP yang dapat memfasilitasi aktivitas mikroorganisme dalam melakukan proses fermentasi (Irlbeck, 2000).
Berdasarkan uji antagonis dengan menggunakan metode spread dan point plate hasilnya diperoleh bahwa diantara isolat BAL sebagai starter dinyatakan tidak saling membunuh antar isolat atau hasilnya tidak antagonis.

Viabilitas populasi BAL pada media ransum yang ditambahkan molasses $1,6 \%$ pada media tumbuh mampu menjaga viabilitas BAL yang dapat digunakan sebagai probiotik dalam pengembangan usaha ternak. Hasil penelitian diperoleh populasi bakteri pada media ransum yang ditambahkan molasses $1,6 \%$ (R2) dapat mempertahankan populasi BAL pada jam ke-4 dengan jumlah sel 7,36 x $10^{5} \mathrm{CFU} / \mathrm{g}$, sedangkan populasi bakteri pada media ransum tanpa molase (R1) dapat mempertahankan populasi BAL pada jam ke-6 dengan jumlah sel 6,20 x $10^{5} \mathrm{CFU} / \mathrm{g}$. Viabilitas populasi BAL pada media ransum yang bermolase $1,6 \%$ (R2) mengalami peningkatan terhadap lama waktu penyimpanan pada jam ke-4 yaitu dengan jumlah sel 7,36 x $10^{5} \mathrm{CFU} / \mathrm{g}$, sedangkan pada media ransum tanpa molase (R1) mengalami penurunan jumlah sel 6,08 x $10^{5}$ $\mathrm{CFU} / \mathrm{g}$.

Aplikasi probiotik pada pakan dengan media ransum dilihat dari hasil penelitian, maka sebaiknya sejak preparasinya segera diberikan kepada unggas. Aplikasi probiotik pada ransum unggas ini sebaiknya ditambahkan molase 1,6\%, karena molase merupakan sumber glukosa yang diperlukan oleh probiotik. Dengan demikian, preparasi probiotik pada pakan dengan media ransum bermolase $1,6 \%$ yang terbaik diterapkan pada jam ke-4 dengan jumlah sel 7,36 × $10^{5}$ $\mathrm{CFU} / \mathrm{g}$.

\section{SIMPULAN}

Berdasarkan hasil penelitian yang telah dilakukan diperoleh kesimpulan: penambahan molase $1,6 \%$ dalam ransum (R2) sebagai media dapat mempertahankan jumlah populasi isolate BAL pada jam ke-4 dengan jumlah sel 7,36 x 10 $\mathrm{CFU} / \mathrm{g}$, sedangkan pada media ransum tanpa molase (R1) dapat mempertahankan jumlah populasi BAL yaitu pada jam ke-4 dengan jumlah sel $6,08 \times 10^{5} \mathrm{CFU} / \mathrm{g}$. Viabilitas populasi BAL pada media ransum dengan penambahan molase $1,6 \%$ (R2) mengalami peningkatan terhadap lama waktu penyimpanan pada jam ke-4 yaitu dengan jumlah sel 7,36 x $10^{5} \mathrm{CFU} / \mathrm{g}$, sedangkan pada media ransum tanpa molase (R1) sel 6,08 x $10^{5}$ CFU/g. Selanjutnya dalam media ransum bermolases (R2) populasi BAL dapat bertahan sampai jam ke 7 inkubasi, dengan demikian introduksi BAL dalam ransum selama 7 jam tetap hidup dan preparasi probiotik dalam ransum dapat diterapkan kepada ransum ternak unggas. 


\section{DAFTAR PUSTAKA}

Amrullah, I. K. 2003. Nutrisi Ayam Petelur. Lembaga Satu Gunung Budi. Bogor. Hermawati, A. N. 2013. Viabilitas Bakteri Asam Laktat Yang Diisolasi Dari Rumen Sapi Dalam Media Konsentrasi Molases.Skripsi. Universitas Sebelas Maret. Surakarta.

Hidayat, N.M.C dan Suhartini. 2006. Mikrobiologi Industri. Andi. Jakarta

Irianingrum R. 2009. Kandungan Asam Fitat dan Kualitas Dedak Padi yang di simpan dalam Keadaan Anaerob. Skripsi. Fakultas Peternakan. Institut Pertanian Bogor. Bogor.

Irlbeck, N.A. 2000. Basics of Alpaca Nutrition. Alpaca Owners and Breeder Association Annual. Conference Proceedings. June 4. Louisville.

Kristiyanti, M. 2015.Viabilitas Bakteri Asam Laktat (BAL) Pada Media Tumbuh yang Dimodifikasi dengan Tepung Ikan.Skripsi. Universitas Lampung.Lampung.

Mardiani A, Juni S, Triana S. 2013. Total Bakteri Asam Laktat, Kadar Air dan Protein Keju Peram Susu Kambing Yang Mengandung Probiotik Lactobacills casei Dan Bifidobacterium longum. Jurnal Ilmiah Peternakan 1(1) : 244-245. Fakultas Peternakan. Universitas Jendral Soedirman. Purwokerto

Moat, G.A., W. J. Foster And P.M. Spector. 2002. Microbial Physiology. fourth edition. Wiley Liss. United States of Amerika.

Pelczar, J. M., E. S. C. Chan, R. K. Noel dan D. E. Diane. 1993. Microbiology Concept and Application. MC Graw Hill. New York

Pelczar MJ dan E.C.S. Chan. 2005.Dasar-Dasar Mikrobiologi 2. Jakarta: Universitas Indonesia.

Priyono. 2009. Penggunaan Molases Untuk Meningkatkan Pupuk. Mahasiswa Magister Ilmu Ternak UNDIP. Semarang. Fakultas Peternakan, Universitas Ponogoro.

Saputro, B. 2016.Pengaruh Ransum Yang Berbeda Pada Itik Jantan Terhadap Jumlah Leukosit dan Diferensial Leukosit. Skripsi. Universitas Lampung. Lampung.

Supriyanto, A., A.N. Heryani, Ni'matuzahroh 2012. Studi Viabilitas dan Pola Pertumbuhan Bacillus megaterium pada Konsentrasi Molase dan Waktu Inkubasi yang Berbeda. Program Studi S-1, Biologi, Departemen Biologi Fakultas Sains dan Teknologi, Universitas Airlangga agussupriyanto@unair.ac.id.

Sutrisna, R. 2013. Karakterisasi isolat Bakteri Asam Laktat dari Usus Itik (Anas domestica) Terhadap Escherichia coli dan
Salmonella pullorum. Makalah Seminar Nasional Sains \& Teknologi V, Lembaga Penelitian Universitas Lampung.

Tarigan, T. N. 2010. Penggunaan Asam Amino Metionin dan Lisin dalam Ransum Terhadap Karkas Broiler Umur Enam Minggu. Skripsi. Fakultas Pertanian. Universitas Sumatera Utara. 